\title{
THE METHODICAL CUBE AND THE PROJECT TOOLS AS AN INNOVATIVE APPROACH TO BUSINESS PROCESS MODELLING
}

\author{
[Methodical cube a projektové nástroje jako inovativní př́istup k modelování \\ podnikových procesů] \\ Marcela Koval'ová ${ }^{1}$, Lukáš Turčok ${ }^{2}$ \\ ${ }^{1}$ Matej Bel University, Faculty of Economics, Tajovského 10, 97590 Banská Bystrica, \\ Slovak Republic \\ Email: marcela.kovalova@umb.sk \\ ${ }^{2}$ Technical University of Liberec, Faculty of Economics, Voroněžská 13, 46002 Liberec 2, \\ Czech Republic \\ Email:lukas.turcok@tul.cz.
}

\begin{abstract}
The article deals with the problem of business processes modelling. It presents the basic theoretical concepts and proposals how to use various methods of business processes modelling for various levels and attributes of these processes through the created methodical cube. The methodical cube is the methodology of the process model (or map) creation as well as the innovative tool in process management. The objective of this article is to create the basis for business processes optimization and for improving their performance through "the three aspects methodology" required for the business processes modelling and design. The authors mention the project approach to process modelling. They use an analysis of problems (so-called "tree of problems") and analysis of goals (socalled "tree of goals) as project tools, which should be applied before process modelling. These tools help the process manager to understand potential problems and find the goals for making a good process map or model.
\end{abstract}

Keywords: business process, methodical cube, modelling, process model.

JEL Classification: C60, M10, M21

Doručeno redakci: 26.8.2013; Recenzováno: 30.4.2014; 10.5.2014; Schváleno k publikování: 27.5.2015

\section{Introduction}

The business processes identification and the knowledge of the maximum number of elements and characteristics of each process provide company a competitive advantage and also an adequate basis for the creation of the process model. In preparing of such process model a company obtains detailed information of this process and, moreover, can identify hidden, yet unknown, information specific for the analysed business process. Therefore it is very important to focus on the area of the business processes, their structure and companies should work on their improvement, thus optimizing in the constantly changing dynamic business environment.

The objective of this article is to create the basis for business processes optimization and for improvement of their performance through "the three aspects methodology" required for the business processes modelling and design. And also to show the project approach to process modelling. The article is divided into four chapters. In the first chapter we describe a theoretical preview of the problem. The second chapter is a summary of methodology. And in the chapter three and four we show innovative approaches to business process modelling through the methodical cube and the project tools. 


\section{Literature preview}

The process is a sequence of steps or activities (actions) performed to achieve a specific and measurable purpose. The process model or map consists of individual actions, activities, procedures and the relations among them, which the company realizes in its business. We present this scheme in the graphical form mostly created by computer program. Then we allocate to particular steps the resources, which are necessary for the operation.

As argued in Valášek (2005) the process model is the basis of process management. It can be drawn on the paper, created in simple programs like Microsoft Visio or through sophisticated tools such as ARIS from IDS Scheer. ARIS helps to create a process map with more levels, so it can represent the process, its sub-processes and activities. The model includes mutual relationships among processes and helps to link processes with concrete job positions.

Modelling a process is called the "business process design" as well. According to Laguna and Marklund (2005), the business process design is concerned with configuring the process architecture (i. e. the inputs and outputs, the flow units, the network of activities and buffers, the resources, and the information structure) in a way that satisfies customer requirements in an efficient way.

The process model (map) is a graphic representation of business processes, sub-processes and activities and their associations. The process model helps to understand how processes of company work and allows to communicate graphical verbalization of reality to all employees.

Business processes must be effective and efficient. It is very useful to display processes in the process map, which allows finding out the critical points of the process and optimize it. Effective processes can create a competitive advantage, which can be decisive in the external environment. Therefore it is very important to focus on the area of the business processes, their structure and companies should work on their improvement. Author Davis (2009) asks himself, what makes a "good process"? He argues there is not a simple answer. He claims things are not so simple and there is a difference between what makes a good process and what makes a good process model. It is possible to have a good process model of a poor process, but it is not possible to have a good process without a good model or design.

The process is the "definition of the tasks and the sequence of those tasks necessary to fulfil an objective." The same author identifies a set of criteria for a good process. A good process must:

- deliver something of value to someone outside of the process,

- create value for the organization operating the process,

- align with corporate values and strategy.

As we can see processes do not stand by themselves in isolation, and, hence, when designing or modelling a process, we need to think about more than the process flow. A "process model" must describe:

- the definition of tasks,

- the sequence of tasks,

- the resources needed to operate them,

- the environment in which they operate,

- the business objectives they fulfil.

1 DAVIS, R., 2009. What makes a good process? [online]. [cit. 09. april 2013]. Available from: http://www.bptrends.com/publicationfiles/FIVE11-09-ART-Whatmakesagoodprocess-BPTrends.pdf 
A good process is one that is effective, efficient, relevant, valid, and usable, used, reused, managed and measured (Davis, 2009).

Authors Vymětal et. al. (2008, p. 93) say that "the process modelling is based on the following principles:

- the subject of the modelling are material and information processes in the company,

- the result of the modelling process is a functional model, which consists of a process model of the existing system, of the list of actions, process model of the proposed system, the real model and the organizational structure of the company."

Modelling techniques are like sand on the beach. They seem to exist in millions of variants, fashions and styles. Recker (2006) started the effort to compile a list of process modelling techniques in use and stopped at the count of 3,000. Many of these have been developed for a specific modelling purpose.

Unified modelling language (UML) activity diagrams can be used to model processes, but they come from a software engineering background and were not designed for business modelling in the first place. Modelling tools should support the utilization of process models for various purposes - for instance, simulation, analysis, reporting, performance management, execution, and god knows what else (Recker, 2006).

As this list indicates, process modelling efforts may range all the way from pure documentation purposes (for which a SmartDraw tool might just be appropriate) down to workflow specification and enactment.

"For easier understanding of the processes are nowadays used the 3D animation and the virtual reality, which allow to work with real objects and distances directly on the computer" (Manlig, Havlík, 2004, p. 1). There are various types of software applications (next "SA") used for business processes management and their performance management. The software allows managing business processes, to manage their performance, to identify critical points and error situations in an easier, faster and more sophisticated way. The use of SA in company is significantly different, particularly in terms of its size, number of employees, number and complexity of the identified processes and also management concepts, with regard to the scope of using the tool. The indisputable criterion in deciding of the company is the price for SA and possibly other components, as well as the vendor's representation in the Slovak and/or Czech Republic or at least the possibility of technical support from the supplier. Small businesses, which don't need to describe in detail the difficult and complex business processes, don't use complicated tools; these companies will be oriented rather to simplicity and comfort of use and the decisive criterion will be the costs associated with purchase SA. On the other hand, big companies or companies with a large number of identified processes appreciate a tool with more functions, with the possibility of additional training courses from the supplier of SA or from another consulting company or the possibility of simulation and connection the business processes management with IT systems or with other projects (quality management, Six Sigma, etc.). The overview of software tools for process management support is given in the table 1 . There are many software tools for modelling and simulating of business processes. In the table 1 we describe selected software tools with their basic web address. 
Table 1: Software tools

\begin{tabular}{|c|c|c|c|}
\hline $\begin{array}{l}\text { Software } \\
\text { Application }\end{array}$ & Web address & $\begin{array}{l}\text { Software } \\
\text { Application }\end{array}$ & Web address \\
\hline Adonis & http://www.boc-group.com & Mega Suite & http://www.mega.com/ \\
\hline $\begin{array}{l}\text { Agilense EA Web } \\
\text { Modeler }\end{array}$ & http://www.ebizq.net/ & Metastorm BPM & http://www.metastorm.com/ \\
\hline $\begin{array}{l}\text { Arena Simulation } \\
\text { Software }\end{array}$ & http://www.arenasimulation.com & Microsoft Visio & http://office.microsoft.com/ \\
\hline $\begin{array}{l}\text { ARIS Business } \\
\text { Simulator }\end{array}$ & http://www.ids-scheer.cz/ & Oracle Designer & http://www.oracle.com/ \\
\hline $\begin{array}{l}\text { CA ERwin }{ }^{\circledR} \\
\text { Process Modeler }\end{array}$ & http://www.ca.com/ & $\begin{array}{l}\text { ProModel Process } \\
\text { Simulator }\end{array}$ & http://www.promodel.com/ \\
\hline Caci SimProcess & http://www.caciasl.com/ & ProVision & http://www.proformacorp.com/ \\
\hline $\begin{array}{l}\text { CaseWise } \\
\text { Corporate Modeler } \\
\text { Suite }\end{array}$ & http://www.casewise.com/ & QPR ProcessGuide & http://www.qpr.com/ \\
\hline Envision & http://www.future-tech.com/ & $\begin{array}{l}\text { Select Business } \\
\text { Modeler }\end{array}$ & http://www.selectbs.com/ \\
\hline $\begin{array}{l}\text { Holocentric } \\
\text { Modeler }\end{array}$ & http://www.holocentric.com/ & SilverRun BPM & http://www.silverrun.com/ \\
\hline IBM BPM Suite & http://www-03.ibm.com/ & $\begin{array}{l}\text { Sparx Systems } \\
\text { Enterprise Architect }\end{array}$ & http://sparxsystems.com/ \\
\hline $\begin{array}{l}\text { IBM Websphere } \\
\text { Business Modeler }\end{array}$ & http://www-306.ibm.com/ & $\begin{array}{l}\text { Sybase } \\
\text { PowerDesigner }\end{array}$ & http://www.sybase.com/ \\
\hline iGrafx & http://www.igrafx.com/ & $\begin{array}{l}\text { SAS Strategic } \\
\text { Performance } \\
\text { Management }\end{array}$ & http://www.sas.com/ \\
\hline $\begin{array}{l}\text { Interfacing BPMN } \\
\text { Modeler }\end{array}$ & http://www.interfacing.com/ & StarUML & http://staruml.sourceforge.net/ \\
\hline $\begin{array}{l}\text { Jaczone Essential } \\
\text { Modeler }\end{array}$ & http://www.jaczone.com/ & Witness & http://www.lanner.com/index.cfm \\
\hline
\end{tabular}

Source: Own processing by Řepa (2007), edited by authors.

As seen on the table 1, there are many accessible software applications and it's on user which criteria will be used. There is only a selection (not of software applications in the table, which are available on the market.

\section{The methodology}

The objective of this article is to create the basis for business processes optimization and for improving their performance through "the three aspects methodology" required for the business processes modelling and design, and also to show the project approach to process modelling.

The methods used in this article are as follows: abstraction, analysis, synthesis, comparison, generalization, analogy. We use an analysis, synthesis and comparison in introduction to business process modelling. In section 3 we describe the methodical cube and we use an abstraction (by creation of methodical cube) and a generalization of three aspects of process modelling (the method of modelling, the content displayed by process map and the attribute of process). In section 4 we present an analysis of problems in process modelling (the socalled tree of problems) and an analysis of goals (the so-called tree of goals). By applying an analogy with project management, we describe the tree of problems and the tree of goals to find the links between causes and effects and between means and goals in process modelling. 


\section{The methodical cube}

Creation of a process map should take into the consideration:

- the method of process modelling and the related software tool define HOW we want to model,

- the content displayed by the process map and the level of the view define WHO is the user of process map,

- the attribute of process determines WHAT we want to model.

The most important aspect is the choice of the method of process modelling which will be used. We have to decide about this method even before we create a model of the business process. Modelling possibilities and related restrictions of the process modelling depend on the choice of the modelling method. The users of the modelling methods and tools have usually many expectations. They consider many criteria in order to choose the appropriate method and tool for modelling processes.

In order to include the various aspects of the process modelling, we have created methodical cube. We use an example to demonstrate the methodical cube and the way how it can be used. The main purpose of using the cube is to choose the appropriate method of process modelling (we take into consideration that the method is almost always connected with the software tool). The methodical cube represents the combination of important aspects which could be considered. It can be used as the tool for users in decision making.

The methodical cube we mentioned above is positioned in three axes ( $\mathrm{x}, \mathrm{y}$ and $\mathrm{z}$ ). Each axis of the cube is divided into several parts, sections. The number of parts is the choice of the user (process modeller). The axis $\mathrm{x}$ represents the modelling space (which is closely connected with the software tool), the axis y represents the optimization and simulation possibilities and the axis $\mathrm{z}$ represents the level of modelling difficulty. By each combination of a specific section in the axes $\mathrm{x}, \mathrm{y}$ and $\mathrm{z}$ it is possible to determine the point (taking into consideration that each axis can be divided into different number of parts). Each point in the cube represents certain combination of the modelling space, the level of modelling difficulty and the optimization and simulation possibilities. We note the points in the cube "p" and each of them is determined by 3 components of a vector (represented by the axis $\mathrm{x}$, axis $\mathrm{y}$ and axis $\mathrm{z}$ ), so we use the notation as follows: $\mathrm{p}=[\mathrm{x} ; \mathrm{y} ; \mathrm{z}]$. As the default starting point we have set the intersection of the axes $\mathrm{x}, \mathrm{y}$ and $\mathrm{z}$ with the coordinates of 0 . As an example, we are using the methodical cube divided into 36 points, so the axis $\mathrm{x}$ is divided into 4 parts, the axis $\mathrm{y}$ into 3 parts and axis $z$ into 3 parts, as it is shown in Figure 1. 
Figure 1: Graphic proposal of the methodical cube for two points "p"

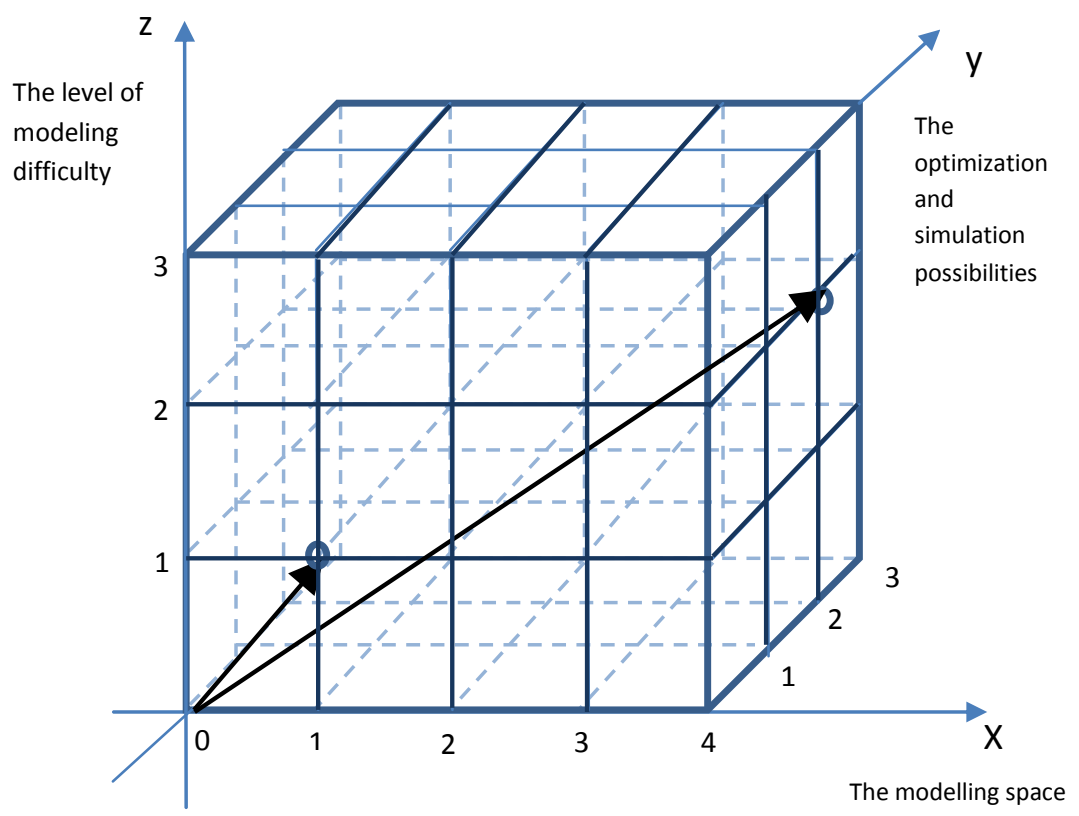

Source: Own processing.

We have chosen the ascending arrangement of the figures in the axes (from 1 as a minimum up to 4 as a maximum of figures in the axis $x$, from 1 as a minimum up to 3 as a maximum of figures in the axis $y$, and from 1 as a minimum up to 3 as a maximum of figures in the axis $\mathrm{z}$ ).

By looking for the appropriate method of process modelling the user could follow these steps:

- to determine the process modelling purpose and the objectives,

- to decide the aspects which have to be included in modelling the processes (we use the modelling space, optimization possibilities and modelling difficulty as the examples),

- to set the arrangement and the scale of the figures in the axes (the user can use the own experiences, available sources and/or the experts opinions),

- to select the methods which have to be considered and to match the methods with the corresponding vector co-ordinates (to evaluate the methods),

- to use the Euclidean distance (or Euclidean metric) as a tool for comparisons among the modelling methods. Euclidean distance in the mathematics is the "ordinary" distance between two points that one would measure with a ruler and is given by the Pythagorean formula.

For the Euclidean distance $(d)$ of the point "p" from the default starting point 0 we use the equation as follows:

$d(p)=\sqrt{x^{2}+y^{2}+z^{2}}$

where $p$ represents particular point in the cube and $x, y, z$ stand for the symbols of vector components.

In the methodical cube we use the Euclidean distance to find out the distance between that particular point from the cube as the combination of the three dimensions (axes) belonging to the specific modelling method and the default point (zero). Then the distances (results) 
obtained for several points (i.e. for different methods) are compared each other and the worst/the best method for the modelling of processes can be set. The key is to evaluate the methods by using the methodical cube and to find out the distances between particular points (represent the evaluated methods) and the default point. The worst method is the method with the worst result (minimum distance) and the best method is the one with the best result (maximum distance between the point and zero).

As we mentioned above the methodical cube-approach has not to be considered a new modelling approach or modelling method. It is designed in order to describe or graphically explain the using of multiple points of view in the process modelling. The appropriate modelling method can be chosen according to the described methodology.

The presented example is only one way how to look at the process modelling. We can elaborate the cube in the form of vector in the following way: $\mathrm{p}=\left[p_{1} ; p_{2} ; p_{3} ; \ldots p_{n}\right]$, so we can take multiple variables or criteria into the consideration (more than three as we mentioned in the example). The following potential criteria which can be chosen: the possibility to use a guide (methodical guide how to use the method), the level of graphical description, the possibility to create the organizational structure, the editor, by using the software tool - the technical support, the possibility of zoom, the supported methodology, the price, etc..

The methodical cube should facilitate the creation of the process maps in the company, allows to combine and to appreciate three or multiple fundamental aspects of the process modelling and helps to choose the appropriate combination. The selection and the definition of these aspects is the basis for the process model of high quality.

\section{Project approach to business process model}

Business process modelling is a complex of activities and the creation of process model should be conceived as a project. A project is a sequence of activities (steps), characterised by the clearly defined start and end, with limited resources and external and internal risks as well. The output of a project should be delivered with required quality. A set of project management tools can be used for identification and analysis of "causes and effects" in the process modelling.

For example, to analyse the most common problems of process modelling we can use an analysis of problems and goals, "the tree of problems" (figure 2) and "the tree of goals" (figure 3). The analysis of problems is a methodical project management approach used to identification of negative aspects of the current situation (e.g. problems of process modelling) and to capture relations between causes and effects. The analysis of goals is the approach used to description of the required situation (e.g. objectives of creation of process model), hierarchical organizing of goals and capture of links between means and goals. 
Figure 2: The analysis of problems (the tree of problems)

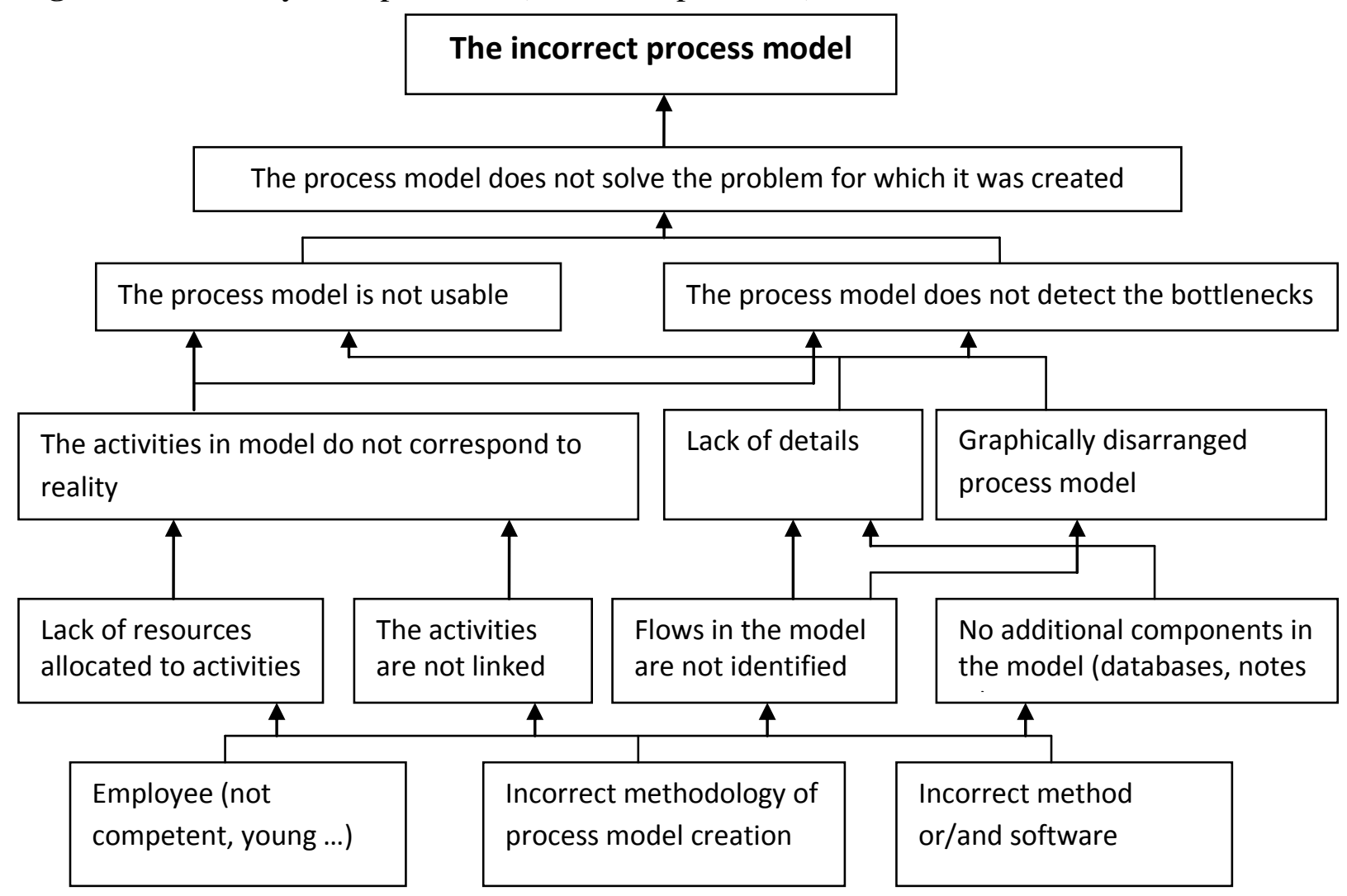

Source: Own processing.

As we describe in figure 2, an incorrect process model could be the effect of three basic causes: 1.) a not competent or young employee who creates a process model, 2.) incorrect methodology (or procedure) of process model creation and 3.) an incorrect method or/and software used for creation of the process model. The result of many problems that arose on the start of process modelling is an incorrect process model which doesn't correspondent to requirements of client /or somebody who is going to use a model/. An incorrect process model doesn't solve the problem for which it is created, so the client isn't satisfied. The causes of this incorrect and "no-helpful" process model are related with these situations: the process model is not usable and/or the process model doesn't detect the bottlenecks. By using this tree we can find many situations/causes which create the problems (not usable process model or model without detecting the bottlenecks). Once we solve the causes on the "base" of this tree (as if roots of the tree - e. g. an employee not competent for creation of model, incorrect methodology or method/software for creation), we can avoid accumulation of problems and creation of the useless process model (moreover, very expensive for a company).

If we want to realise an analysis of goals in process modelling we can use the similar tree. Instead of the problems we work with goals and construct a tree of goals (figure 3). By using this analysis of goals, a required situation can be described and links between means and goals can be identified. 
Figure 3: The analysis of goals (the tree of goals)

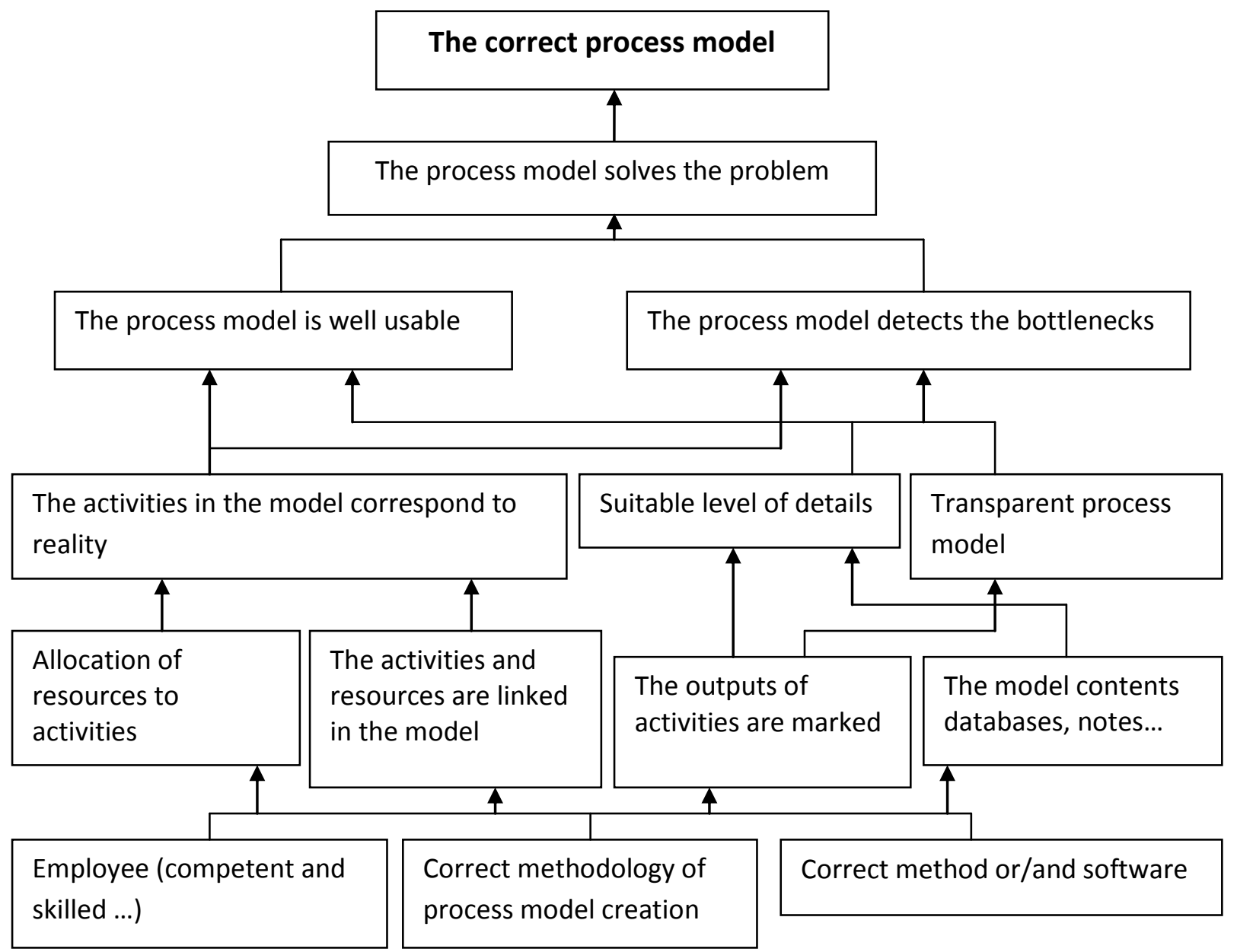

Source: Own processing.

We should note that there is the long way, consisting of many steps, from the process analysis through process modelling to management and actualisation of process model. The project of process modelling consists of particular steps:

- process identification,

- process analysis,

- creation of the process model - process modelling or design,

- creation of link between processes,

- identification of bottlenecks in processes,

- elaborating list of possibilities how to eliminate bottlenecks,

- bottlenecks optimizing,

- administration and updating of the process model.

The process modelling is usually decomposed into:

- analysis of activities in processes,

- allocation of resources in activities,

- definition of process attributes,

- definition of indicators of process performance,

- allocation of competencies to indicators of performance. 
The process model creation is usually the basic phase of "implementation project" of process management in the company. It is based on the existing documentation in company (methodical instructions, directives, documentation of quality system etc.). The creation of process model based on documentation is the important step of process modelling, which helps to reconsider the current condition (status) of process management in company. Creation of pilot drawings is followed by the process analysis and modelling of all business processes, the analysis of bottlenecks and optimization of process model (map).

The process analysis and process modelling could take a few months, depending on the type, size of company (number of employees) and number of processes.

The project approach to business processes modelling helps to understand, what causes are producing an effect in the process model and to understand how the objectives should be set to create a correct process model.

\section{Conclusion}

The main objective was to create the basis for business processes optimization and improving their performance through "the three aspects methodology" required for the business processes modelling and design, and to describe the project approach to process modelling.

The methodical cube could be the basis for the creation of the process map, because it provides a complete view on various aspects of the process modelling and it allows selecting the most appropriate modelling method. From the choice of the modelling method then there unfolds the quality, transparency, completeness and reasonableness of the created process model, which represent the basis for the successful business processes optimization and their improvement.

The project approach facilitates the creation of the process model (map) by decomposition of the complex task to partial activities. The use of the problem analysis (so-called the problem tree) and the use of the objectives analysis helps to understand the basic causes of possible failure of the process model creation and also to understand the aims supporting creation of the correct process model. Afterwards the correct process model is applicable for solving problems in processes of the company.

\section{Acknowledgement}

This work was supported by ESF operational programme "Education for Competitiveness" in the Czech Republic in the framework of the project "Support of engineering of excellent research and development teams at the Technical University of Liberec" No. CZ.1.07/2.3.00/30.0065.

\section{References}

[1] DAVIS, R., 2009. What makes a good process? [online]. [cit. 09. april 2013]. Available from: http://www.bptrends.com/publicationfiles/FIVE11-09-ART-Whatmakesagood process-BPTrends.pdf

[2] LAGUNA, M. a J. MARKLUND, 2005. Business process modeling, simulation and design. New Jersey: Pearson Education, Inc. ISBN 0-13-091519-X.

[3] MANLIG, F. a R. HAVLÍK, 2004. Witness a jeho pozice ve výuce výrobních systémů. In: Witness 2004. Brno: Humusoft s.r.o. \& VUT Brno - Fakulta podnikatelská, s. 1-4. ISBN 80-214-2671-3. 
[4] RECKER, J., 2006. Process Modeling in the 21th Century [online]. [cit. 08. april 2013]. Available from: http://www.bptrends.com/publicationfiles/05-06-ART-ProcessModeling 21stCent-Recker1.pdf

[5] ŘEPA, V., 2007. Podnikové procesy. Procesní ř́zení a modelování. 2., aktualizované a rozšířené vydání. Praha: Grada Publishing. ISBN 978-80-247-2252-8.

[6] VALÁŠEK, M., 2005. Zavedenie procesného riadenia treba dotiahnut' do konca. Týždenník Trend [online]. 7. 4. 2005 [cit. 05. april 2013]. Dostupné z: http://www.etrend.sk/trend-archiv/rok-/cislo-Apríl/zavedenie-procesneho-riadenia-trebadotiahnut-do-konca.html

[7] VYMĚTAL, D. et al., 2008. Production planning model using REA ontology. Ekonomie a Management, 11(4), 93-102. ISSN 1212-3609. 